\title{
The Effect of Indirect Compensation on Employee Performance in Daluman Villa Kuta Bali
}

\author{
Sri Sukmawati Wijaya*1, Luh Putu Kartini'2, I Ketut Surata ${ }^{3}$, Raissa Puspita ${ }^{4}$ \\ Politeknik Pariwisata Bali, Indonesia1,2,3,4 \\ Email: hsrisukmawati32@gmail.com
}

\begin{abstract}
During the pandemic situation, take interest to indirect compensation in order to maintain employee performance becomes very important while increasing direct compensation will be difficult. The purpose of this study is to find out the significance effect of indirect compensation toward employee performance based on criteria of Byars and Rue' indirect compensation model and Sedarmayanti's employee performance model. Mixed method is chosen in this research to study the employee perception of Daluman Vila using questionnaire with census method and elaborate it with interview result. The quantitative data is then analyzed using simple regression test, meanwhile the qualitative data is analyzed using descriptive analysis and triangulation. The result shows that employees supporting facilities in indirect compensation criteria, and initiative in employee performance, obtained lowest score. To improve these aspects, evaluation related to supporting employee facilities and designing employee performance indicator for Daluman Villa personal use are suggested to be done.
\end{abstract}

Keywords: Indirect Compensation; Employee Performance; Hotel; Situasi Pandemi

\begin{abstract}
Abstrak
Dalam situasi pandemi, mengelola kompensasi tidak langsung untuk mempertahankan kinerja karyawan dapat menjadi alternatif ketika memberikan kompensasi langsung, sulit untuk dilakukan. Tujuan penelitian ini adalah untuk mengetahui pengaruh kompensasi tidak langsung terhadap kinerja karyawan berdasarkan kriteria model kompensasi tidak langsung oleh Byars dan Rue dan model kinerja karyawan oleh Sedarmayanti. Metode campuran dipilih dalam penelitian ini untuk mempelajari persepsi karyawan Daluman Vila menggunakan kuesioner dengan metode sensus dan diuraikan dengan hasil wawancara. Data kuantitatif dianalisis menggunakan uji regresi sederhana, sedangkan data kualitatif dianalisis dengan analisis deskriptif dan triangulasi. Hasil penelitian menunjukkan bahwa kompensasi tidak langsung berpengaruh terhadap kinerja karyawan, dimana fasilitas penunjang pegawai dalam kriteria kompensasi tidak langsung, dan inisiatif dalam kinerja karyawan memperoleh nilai terendah. Untuk meningkatkan aspek-aspek tersebut maka evaluasi terkait fasilitas penunjang karyawan dan perancangan indikator kinerja karyawan di Daluman Villa disarankan untuk dilakukan.
\end{abstract}

Kata Kunci: Kompensasi tidak langsung; Kinerja Karyawan; Hotel

\section{A. INTRODUCTION}

Daluman Villa is a five-star private villa that concerns about their human resource matters as a way to compete against its competitors. Nowadays, the number of hotels in Bali is growing fast which caused an increased competition. Considering the increased competition, it is necessary for company to identify and retain the competent employees in the organization to maximize its performance. Located within the lifestyle district of Seminyak, in order Daluman Villa to be able to compete with other hospitality industry businesses, it is necessary to pay attention and keep improving the quality of products and services through employee performance (Rucika, 2020) The employee performance in Daluman Villa is already

\footnotetext{
* Corresponding author

Received: August 03, 2020; Revised: November 17, 2020; Accepted: December 28, 2020
} 
good which can be shown on customer reviews score on online travel agents such as TripAdvisor, Google Review, Traveloka and Booking.com.

Based on the initial interview conducted with the General Manager of Daluman Villa, Rudi Ryiadi, there are two types of compensation provided such as direct compensation and indirect compensation. The provided direct compensations are salary based on average minimal wages in Badung Regency (UMK), meal allowance and THR allowance (annual labor allowance). The provided indirect compensations are national health insurance/BPJS Kesehatan \& BPJS Ketenagakerjaan, annual leave, paid days off, award program and facilities (locker room and parking area). These compensations are provided in order to improve the employee performance of the villa.

Under the broad area of human resource management practices, compensation is a specific area of study which is significantly related to job performance (Becker, B. E., \& Gerhart, 1996; Becker, B. E., \& Huselid, 1998; Bloom, M., \& Michel, 2002). Indirect compensation is considered very important because it affects the well-being of the individuals in the organization. Indirect compensation helps organization to attract and retain highly competitive employees which are seen as strategic resources in getting competitive advantage (Becker, B. E., \& Gerhart, 1996). These theories show that compensation is highly related to job performance. Indirect compensation can provide a competitive advantage for the company. One of the most important reasons in providing indirect compensation is to show that the company cares and value the employees' contribution, because employees are one of the most valuable assets (Dessler, 2011), In developing countries like Indonesia, people tend to focus more on direct compensation instead of indirect compensation. However, in a developed country such as United States of America and United Kingdom, it is important for hotel industry HR executives to pay greater attention to the nature and level of benefits being offered to non-management employees (Becker, B. E., \& Huselid, 1998)

According to Organization for Economic Co-operation and Development (DECD) due to worldwide pandemic it is projected that world's economy will be minus $6 \%$ to $7,6 \%$. This show how difficult the economic condition is during pandemic. The economic growth in Indonesia in 2020 is projected by the government to be minus 4,3\% to 5\% (KOMPAS.com, 2020). Currently, the economic condition of developing country like Indonesia during the pandemic is very unstable. In this case, indirect compensation on employee performance could be an option since increasing direct compensation will be difficult for the company. (Rudy Ryiadi, 2020; Rucika, 2020).

The management of Daluman Villa wants to know how significant the effect of indirect compensation on employee performance during the worldwide pandemic situation so the management would like to know the significance from the employees' perspective. Based on previous research on the empirical review, indirect compensation has a positive effect on employee performance. Especially during pandemic, indirect compensation can be very beneficial for the employee when the villa is temporarily closed. The employee receives less direct compensation but they still received the indirect compensation in the form of health insurance. Health insurance like BPJS Kesehatan is actually very useful during the pandemic situation in case they need medical care but it is actually important even if there is no pandemic. This is also confirmed by the hospitality expert during the focus group discussion that indirect compensation such as health insurance is very important in this current situation of pandemic.

The main theory used in this research for indirect compensation indicator is by Byars and Rue (2008). This theory is chosen based on the previous research of Nuray Akter and Md Moazzam Husain (2016). The previous study is conducted based in Malaysia. Since the country context of Malaysia and Indonesia is similar, author decided to use the same theory as a foundation. Other than that, this theory is also popular since it is used by a number of researches such as by (Ahmed, 2014). The main theory used for employee performance indicator is by Mitchell in Sedarmayanti (Sedarmayanti, 2011). The theory is chosen because the majority customers of Daluman Villa are from developed country such as Australia 
and UK. So, the employee performance indicator theory is chosen from a developed country which is expected by the customer. Therefore, the employee performance indicator will match with the customer expectation.

Byars and Rue ((Byars \& Rue, 2008)) refers to Indirect Compensation Model and is used because it is related to the research topic and because it is a popular theory that is used by previous research, which contains: Social Security, Workers' Compensation, Retirement Plans, Paid Holidays, Paid Vacations and Other Benefits. Meanwhile, the base theory used for employee performance indicator is by Mithcell in Sedarmayanti (Sedarmayanti, 2011)because the theory is chosen to match with the employee demographic background with the model as follows: Quality of Work, Initiative, Punctuality, Capability, and Communication.

There are some previous researches that are related to this study which is effect of indirect compensation on employee performance. First are research done by Hana Laura (2012) shows that there is no real effect of direct compensation on employee performance meanwhile indirect compensation has a real effect on employee performance. The second study is by Mashal Ahmed and Abu Bakar Ahmed ((Ahmed, 2014)) that shows the impact of indirect compensation on employee performance is positive.

Therefore, the aim of this research is to know the effect of indirect compensation on employee performance in Daluman Villa. It is also aimed to find out the potential improvement could be done through indirect compensation to retain or even improve the employee performance. The research is limited only on the effect of indirect compensation toward job performance in Daluman Villa, Seminyak, Bali. This research is completed within the period of January 2020 to June 2020. The result of this study will provide insight for Daluman Villa which is useful for managerial decision making related to improving employee performance in term of indirect compensation. The research result will also be useful to see the comparison of employees' perspective regarding indirect compensation.

\section{B. RESEARCH METHOD}

This research is using mixed method which includes quantitative and qualitative method. For quantitative method, questionnaire will be used. Meanwhile for qualitative method, interview and focus group discussion will be used. According to (Dessler, 2011)stated that methods should be mixed in a way that has complementary strengths and no overlapping weaknesses. So, this study will use a mix of qualitative and quantitative method. Other than that mixed method is used to study the employees' perspective using questionnaire and turn it into qualitative using interview and focus group discussion.

In this research, both primary and secondary data is used. In this study the primary data will be collected by doing interviews, focus group discussion and questionnaire. For the secondary data, it will be gathered from Daluman Villa itself, including documents regarding compensation types and total number of employees.

In this study, qualitative data will be obtained by doing interview and focus group discussion. In this study, quantitative data will be gathered by using questionnaire. Questionnaire is used to gather employee perception on indirect compensation and will be converted based on likert scale. Meanwhile interview is done to gather data from management perspective and focus group discussion is to gather data from hospitality expert perspective. So, both quantitative and qualitative data in this research is done to seek data from different perspective regarding indirect compensation and employee performance.

The instrument of the research is chosen similarly to the previous research of Nuray Akter and Md Moazzam Husain (2016) because of the similarity of geography. In this study, interview will be conducted with General Manager of Daluman Villa to obtain qualitative data about indirect compensation as well as employee performance in the management point of view. The second method is observation which is a way to collect data through observing. In this study, the observation is done in Daluman Villa. The third 
method used is questionnaire. In this study, the questionnaire will be distributed to all of the population in Daluman Villa which is 40 employees. Sampling method used for this research is census, which all people of the population become the sample because the number of populations in Daluman Villa is relatively small. The last method is focus group discussion which can be defined as gathering people of similar backgrounds to discuss a certain topic of interest. The focus group discussion is done with hospitality expert in Bali.

Data analysis techniques used in this research were: validity, reliability, simple linear regression, ttest and determinant coefficient test done by SPSS version 23 . Validity test is done to ensure the validity of the research. Reliability test is done to ensure the accuracy and consistency of the test. Simple linear regression test is done to determine the relationship between the variables. T-test is done to measure the impact of indirect compensation toward employee performance. Meanwhile determinant coefficient test is done to measure how capable the indirect compensation can explain the employee performance.

The qualitative data analysis technique used in this research is descriptive analysis and triangulation. Descriptive analysis examines the quantitative and qualitative data collected through methods such as interview, focus group discussion and document analysis. The informational content is shown in a straight and descriptive summary structured according to the needs of the study. Meanwhile triangulation is a technique to test the validity of data from different perspectives. In this research, the data is gained from employees (questionnaire), from general manager (interview) and hospitality expert (focus group discussion). The data analysis technique for both quantitative data and qualitative data is chosen similarly to previous research on empirical review that used the same method of collecting data.

As suggested by the theory and the previous studies, indirect compensation has a positive effect on employee performance. Therefore, there are two hypotheses tested in this study. The first is H1: indirect compensation $\left(\mathrm{X}_{1}\right)$ has a positive significant effect on employee performance $\left(\mathrm{Y}_{1}\right)$. The second is $\mathrm{H} 2$ : indirect compensation $\left(\mathrm{X}_{1}\right)$ has no effect on employee performance $\left(\mathrm{Y}_{1}\right)$.

\section{RESULTS AND ANALYSIS}

The data in this study is obtained during the pandemic so the management of Daluman Villa want to see how significant the effect of indirect compensation toward employee performance is. This study is using mixed method which is questionnaire for quantitative data and interview for qualitative data. Due to the Pandemic COVID-19, author is unable to distribute questionnaire and interview directly. The questionnaire is distributed using Google Form which is an online questionnaire. Meanwhile the interview is conducted with the General Manager of Daluman Villa using voice call. The result of the questionnaire will be analyzed using validity test, reliability test, simple linear regression test, t-test and coefficient determinant test. The data obtained from the interview will be analyzed using descriptive analysis and triangulation.

\section{Demographic Information}

Some main demographic information such as age, gender and employment status were gathered from the population ( $\mathrm{N}=40)$. All 40 employees in Daluman Villa are contract worker. The majority of the population is dominated by male with 30 people (75\%) and the remaining 10 people are female $(25 \%)$. The age range is divided into 3 categories. First is 21-30 years old which is dominating with 25 people $(62,5 \%)$. Second is $31-40$ years old that consists of 11 people $(27,5 \%)$. The last remaining is $41-55$ years old with only 4 people (10\%).

\section{Data Description}


In order to provide an overview of the research variables, descriptive statistic analysis will be used by finding the average score (mean) of respondent's assessment on statement items of each variable. On Table 2 is shown the mean score of each indicator for both variables.

Table 2 Data Calculation

\begin{tabular}{lclc}
\hline \multicolumn{1}{c}{ Dimension } & Mean Score & \multicolumn{1}{c}{$\begin{array}{c}\text { Dimension } \\
\text { Eean Score }\end{array}$} \\
\hline Indirect Compensation (X) & & Employee Performance (Y) \\
\hline Social Security & 4,87 & Quality of Work & 4,87 \\
\hline Workers' Compensation & 4,85 & Initiative & 4,76 \\
\hline Retirement Plans & 4,75 & Punctuality & 4,77 \\
\hline Paid Holidays & 4,87 & Capability & 4,92 \\
\hline Paid Vacation & 4,92 & Communication & 4,92 \\
\hline Other Benefits & 4,12 & & \\
\hline
\end{tabular}

As we can see in Table 2, there are total of 11 indicators that produces 11 mean values for both variables. For indirect compensation, there are 6 indicators while for employee performance there are 5 indicators. On the online questionnaire, there are a total of 22 statements that represent 11 indicators for both variables. These indicators are based on Byars and Rue (2008) and Sedarmayanti (2011). For indirect compensation there are 12 statements while for employee performance there are 10 statements. The statements are then presented to the respondents by assessing it from 1 (Strongly Disagree) until 5 (Strongly Agree). The data is then calculated using Mean Score and Interval Class. The result shows that the lowest score for variable $\mathrm{X}$ is criteria 6 and for variable $\mathrm{Y}$ is criteria 2 . These indicate that the other benefits and employee initiative needs to be improved.

Table 3 Score for Other Benefits

(Indirect Compensation)

\begin{tabular}{lcc}
\hline No & Indicator & $\begin{array}{c}\text { Mean } \\
\text { Score }\end{array}$ \\
\hline \multicolumn{1}{c}{ Other Benefits } \\
\hline 12 & Services and facilities for employees are provided & 3,60 \\
\hline Source Pre & There is employee reward program & 4,65 \\
\hline
\end{tabular}

Source: Primary Data Processed (2020)

In Table 3, on Statement 11 and 12 in the questionnaire are representing other benefits. The average result of statement 11 is 3,6 (Good) and statement 12 is 4,65 (Very Good). Statement 11 about services and facilities provided has the lowest average result although it is still considered good. It is then confirmed by the interview answer that stated "there is locker room and parking area provided for employees". This means employees feel there is a lack of service and facilities provided by the hotel, so the hotel should consider this matter. However, statement 12 about employee reward program is confirmed by the interview answer "Every once a year there is employee of the year award." Some improvement that can be done is by adding food services, access to exercise facilities and purchase discounts. For example, by adding cafeteria for the employees then they do not have to go outside the hotel for meal. Giving access to exercise facilities can be done such as by providing gym membership so employees can take care of their health. Then giving purchase discount such as discounts for employees who purchase daily needs on a 
supermarket. By doing these improvements, it will increase the employees job performance that can result in an increase of the overall Daluman Villa performance.

Table 4 Score for Initiative

\section{(Employee Performance)}

\begin{tabular}{|c|c|c|}
\hline & Indicator & $\begin{array}{l}\text { Mean } \\
\text { Score }\end{array}$ \\
\hline \multicolumn{3}{|c|}{ Initiative } \\
\hline 15 & $\begin{array}{l}\text { When the company is facing problems, I do not stay still and provide } \\
\text { useful advice }\end{array}$ & 4,6 \\
\hline 16 & I do my work tasks without waiting for command from superior & 4,92 \\
\hline
\end{tabular}

Source: Primary Data Processed (2020)

In Table 4, for Statement 15 and 16 are representing initiative in the questionnaire. The average result of the statements are 4,6 and 4,92 which is within the very good category although it is the lowest score for employee performance. Statement 15 about employees' initiative to give advice to the company when facing problems has the lowest average result. However, the result is still considered very good. Both of the result is confirmed by the interview answer "So, there are two initiatives such as direct and indirect initiative. Direct initiative for work related and indirect initiative in the form of ideas that are told directly to the supervisor. If it is about making decision on operational issue then the employee is able to do it but if it is about financial decision then the management will make the decision." So, employee initiative is an aspect that can be improved to maximize employee performance.

\section{Table 5 Score for Other Indicator from Indirect Compensation}

\begin{tabular}{|c|c|c|}
\hline No & Indicator & $\begin{array}{l}\text { Mean } \\
\text { Score }\end{array}$ \\
\hline \multicolumn{3}{|c|}{ Social Security } \\
\hline 1 & The social security guarantee is provided corresponding to company's policy & 4,87 \\
\hline 2 & The company has given me wages corresponding to the company's policy & 4,87 \\
\hline \multicolumn{3}{|c|}{ Workers' Compensation } \\
\hline 3 & I received health insurance & 4,92 \\
\hline 4 & I received compensation if there is work accident & 4,77 \\
\hline \multicolumn{3}{|c|}{ Retirement Plans } \\
\hline 5 & Pension fund is provided & 4,87 \\
\hline & There is pension program & 4,62 \\
\hline \multicolumn{3}{|c|}{ Paid Holidays } \\
\hline 7 & National holidays are given corresponding to company's policy & 4,92 \\
\hline & Paid days off are given for important personal affairs & 4,82 \\
\hline \multicolumn{3}{|c|}{ Paid Vacations } \\
\hline 9 & $\begin{array}{l}\text { The amount of vacation days given is already fair corresponding to } \\
\text { company's policy }\end{array}$ & 4,92 \\
\hline 10 & Payment for vacation days are given & 4,92 \\
\hline
\end{tabular}

Based on the result of the questionnaire in Table 5 for Score for Other Indicator from Indirect Compensation, we can find some fact. On statement 1 and 2, the employees in Daluman Villa is satisfied with the provided social security guarantee. The average result of the questionnaire is 4,87 which is considered very good. The questionnaire result is then confirmed with the interview answer that the

104 | Barista: Jurnal Kajian Bahasa dan Pariwisata, Volume 7 Nomor 2, 2020: 97-110 
employees are given social security guarantee in the form of BPJS Ketenagakerjaan. BPJS Ketenagakerjaan already includes work related accident insurance, health care insurance, pension plan and death insurance. So, currently the social security aspect should be maintained.

The workers' compensation is represented by statement 3 and 4 about health insurance and work-related accident in the questionnaire. The average result for statement 2 is 4,92 and statement 3 is 4,77 . Both of the average result is very good which means the employees are satisfied. The interview answer has also confirmed this result. Health insurance is given by in the form of BPJS while work related accident is already covered in BPJS Ketenagakerjaan. Health insurance is considered very important for the employee especially during this pandemic situation. This turns out to be very beneficial so the employee can regularly check their health. This is also stated by the hospitality expert during the focus group discussion. The expert stated that indirect compensation that is usually not considered important by people. However, during this pandemic situation, health insurance turns out to be crucial.

Retirement plans is represented in the questionnaire by statement 5 and 6 . The average result is 4,87 for statement 5 and 4,62 for statement 6 . Both of the result is considered very good. The interview answer has confirmed the result: "There is retirement program. It is already covered in BPJS Ketenagakerjaan". These means that the employees are already satisfied with the provided retirement plans so it needs to be maintained.

Statement 7 and 8 is representing paid holidays in the questionnaire with the average result of 4,92 and 4,82. These results are very good that means employees are satisfied with the paid holidays given from the company. The results can be confirmed by the interview answer as following: "Yes. For national holidays there are also replacements for double the holiday. For example, on 17th August, Indonesian Independence Day, if the employee is working then he/she has the right to receive two days off." In Bali, these paid holidays are considered very precious because there are many Balinese holidays and religious ceremony. Some Balinese holiday is not included in the national holiday so the Balinese employees who need to attend religious ceremony should collect the paid holiday. By collecting the paid holidays, the Balinese employees can use it during the religious ceremonies that are not included in national holiday. For improvement, the management team can include policy that explains about the Balinese holiday and religious ceremony.

Based on the questionnaire, paid vacation is represented by statement 9 and 10 with the same average result of 4,92 which is very good. This means that the employees are already satisfied with the given paid vacation. It is then confirmed with the interview answer "Every employee is given $12+2$ days of annual vacation" It means that employees are satisfied with the given paid vacation. So, the paid vacation is already given fairly between all employees so it should be maintained.

Based on Table 6 above about Score for Other Indicator from Employee Performance, Quality of work is represented in the questionnaire by statement 13 and 14 . The average result is 4,82 and 4,92 which is both considered very good. It means that the employee performance has been able to match the standard work quality of the company. It is then confirmed by the interview answer "So far, every employee has been able to work according to standard".

Punctuality is represented in the questionnaire by statement 17 and 18 with the average result of 4,87 and 4,67 which is considered very good. It means that the employees come to work on time and use the time effectively to finish their work. The result is then confirmed by the interview answer that so far there is no employees who often come late and every employee have been able to finish their work on time.

Statement 19 and 20 in the questionnaire is representing statement 19 and 20. The average result of both statements is very good which is 4,92. This shows that the employees have the adequate skill and able to do their work tasks properly. The interview answers then confirmed these results by stating "In general, they can do their work duties. If they cannot then they will be terminated." 
Table 6 Score for Other Indicator from Employee Performance

\begin{tabular}{|c|c|c|}
\hline & Indicator & Mean Score \\
\hline \multicolumn{3}{|c|}{ Quality of Work } \\
\hline 13 & I can do the work tasks effectively & 4,82 \\
\hline 14 & The company has given me wages corresponding to the company's policy & 4,92 \\
\hline \multicolumn{3}{|c|}{ Punctuality } \\
\hline 17 & While doing my work tasks I use my time as effective as possible & 4,87 \\
\hline 18 & I always come to work on time & 4,67 \\
\hline \multicolumn{3}{|c|}{ Capability } \\
\hline 19 & I have adequate skills to do my work & 4,92 \\
\hline 20 & I can do my work tasks properly & 4,92 \\
\hline \multicolumn{3}{|c|}{ Communication } \\
\hline 7 & I can cooperate in harmony within the team & 4,92 \\
\hline 8 & I always try to be friendly with co-worker & 4,92 \\
\hline
\end{tabular}

Statement 21 and 22 in the questionnaire is representing employee performance based on communication. The result of both statements is 4,92 which is within the very good category. This shows the employees are able to work in team in harmony and are having good relationship with each other. The interview answer then confirmed these results by stating "Small miscommunications do definitely happen before, but it does not impact the operation."

\section{Hypothesis Test}

The validity test is done in order to know the validity or compatibility of the questionnaire used. The result of validity test shows that the smallest coefficient value of a variable indicator is 0.536 . The biggest coefficient value is 0,897 . The overall value of 22 statement items which are indicators of two research variables is 12 items for indirect compensation indicator and 10 for employee performance indicator. In conclusion, all of the statement items are valid because their coefficient value is more than 0,312 . Reliability test is done to show the capability of an instrument to show stability and consistency in measuring a concept. Both of the average value is bigger than 0,6 so can be concluded that all of the statement items from both research variables have fulfilled the reliability data assumption.

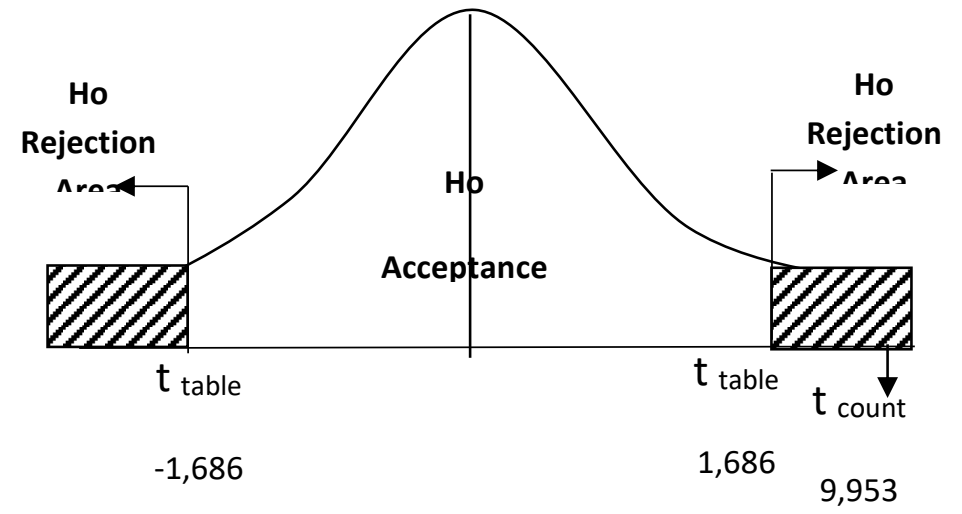

\section{Figure $1 \mathrm{~T}$-Test Distribution Curve of Testing Indirect Compensation (X) on Employee Performance ( $\mathrm{Y}$ )}

As can be seen in Figure 1 about 'T-T'est Distribution Curve of 'Testing Indirect Compensation (X) on Employee Performance (Y), Simple Linear Regression analysis is used to know the change of employee 
performance caused by indirect compensation. The regression coefficient value of indirect compensation on employee performance is 0,610 which means if indirect compensation increased while the other variable is the same then employee performance will increase by 0,610 . Indirect compensation value is positive which means between indirect compensation and employee performance has a positive relation

The last test is coefficient determination analysis. The purpose of coefficient determination analysis is to know the effect magnitude in percentage of the research variables, which are indirect compensation $(\mathrm{X})$ and employee performance $(\mathrm{Y})$.The result of this test is dependent variable is explained by the independent variable as much as 72,3\% (0,723 X 100\%), the rest 27,7\% (100\% - 72,3\%) is explained by other variables which are not used in this research. There are many factors other than indirect compensation that can affect employee performance such as the skill of the employee himself, job satisfaction, motivation, work environment, and many others.

\section{Improvement Needed}

On Table 7 will be shown the summary of improvements needed for the indirect compensation aspect:

Table 7 Summary of Improvement Needed for Indirect Compensation

\begin{tabular}{|c|c|c|}
\hline Criteria & Improvement Needed & Remarks \\
\hline $\begin{array}{l}\text { Social } \\
\text { Security }\end{array}$ & $\begin{array}{l}\text { Need to be maintained since the company already } \\
\text { provided BPJS Ketenagakerjaan }\end{array}$ & \multirow[t]{3}{*}{$\begin{array}{l}\text { These aspects need to be } \\
\text { maintained }\end{array}$} \\
\hline $\begin{array}{l}\text { Workers' } \\
\text { Compensation }\end{array}$ & $\begin{array}{l}\text { Need to be maintained since the company already } \\
\text { provided BPJS }\end{array}$ & \\
\hline $\begin{array}{l}\text { Retirement } \\
\text { Plan }\end{array}$ & $\begin{array}{l}\text { Need to be maintained since it is already included } \\
\text { in BPJS Ketenagakerjaan }\end{array}$ & \\
\hline Paid Holiday & $\begin{array}{l}\text { Add new policy for Balinese Holiday that is not } \\
\text { included on the national holiday. }\end{array}$ & $\begin{array}{l}\text { This will need low cost and } \\
\text { will give slow result in } \\
\text { improving } \\
\text { performance }\end{array}$ \\
\hline Paid Vacation & $\begin{array}{l}\text { Need to be maintained since it is already given } \\
\text { fairly among all employees }\end{array}$ & $\begin{array}{l}\text { This aspect needs to be } \\
\text { maintained }\end{array}$ \\
\hline $\begin{array}{l}\text { Other } \\
\text { Benefits }\end{array}$ & $\begin{array}{l}\text { Adding more supporting facilities and services for } \\
\text { the employee. For examples are food services } \\
\text { (cafeteria), exercise facilities (gym membership) } \\
\text { and purchase discounts }\end{array}$ & $\begin{array}{l}\text { This will need high cost but } \\
\text { will give immediate result in } \\
\text { improving employee } \\
\text { performance }\end{array}$ \\
\hline
\end{tabular}

Source: Primary Research (2020)

\section{CONCLUSIONS}

In order to measure the significance effect of indirect compensation on employee performance there are many test that has been conducted such as simple linear regression test, t-test and coefficient determinant test. All of the test results have shown that an increase in indirect compensation $(X)$ will result in an increase in employee performance $(\mathrm{Y})$. This indicates that indirect compensation has a positive relation with employee performance in Daluman Villa. In conclusion, indirect compensation has a positive and significant effect on employee performance in Daluman Villa.

The result of this research shows there is a shift to employee's perspective about indirect compensation. Before, people do not really value indirect compensation as much and prioritize the direct compensation. However, during the pandemic they realize how indirect compensation is actually very important especially health insurance like BPJS. Hotels during this pandemic have a significant decrease 
on their sales and some hotels are even closed temporarily. So, it will be hard for them to increase employee performance through direct compensation which is why Daluman Villa management is interested in finding out the effect of indirect compensation. During this pandemic, employees are not able to work fully for a week so they receive less salary. Even though they receive less salary, they are still receiving the indirect compensation such as health insurance. This situation has made them realize how indirect compensation is actually very important. It is also confirmed by the hospitality experts during the focus group discussion. They stated that during pandemic, people have realized that indirect compensation like health insurance turns out to be very important. The reason is because with the insurance they can check their health or receive treatment with less cost which is crucial during this pandemic.

This study about the effect of indirect compensation on employee performance has strengths in several aspects. First of all the strength of this research is the result shows the shift of how indirect compensation becomes important due to pandemic. This means that companies should optimize the provided indirect compensation and educate the employees regarding this matter. Another strengths are the research uses mix methods of quantitative (questionnaire) and qualitative (interview) methods. By using mix method, it provides strength that offset the weakness of both quantitative and qualitative research. Thus, by using mix method, the strength of each method can make up for the weaknesses of the other.

However, this study is not perfect and has its own weaknesses. The weakness of this study is due to the worldwide pandemic COVID-19 which is an uncontrollable external factor. Due to the pandemic, it is harder to visit the research venue and gather data. Other than that, it is also harder to consult directly with the research advisor.

The challenge of conducting this study, as has been mentioned before, is due to worldwide pandemic COVID-19. Because of the pandemic, the research venue is not operating normally which makes it hard to visit and obtain data from both questionnaire and interview. It also caused hardship in consulting directly with the research advisor. In order to pass the challenge, the questionnaire form is distributed online using Google Form and to contact the General Manager using online communication via Whatsapp. To overcome the challenge of consulting directly with the research advisor, the consultation session is done through online media such as Whatsapp and Zoom by sending message, voice call and video call.

Author recommendation for future studies is to conduct the research in an ideal timescale to avoid uncontrollable factors like pandemic COVID-19 which can hamper the progress of the research. It can hamper the research progress such as not being able to do face to face interview and distribute the questionnaire directly. Other than that, the limitation of this research is it only focuses on one factor that can affect employee performance while there are many factors that can affect it. So, author suggest future studies to include more variables that can affect employee performance such as direct compensation, work environment, motivation, training program and many others. Another suggestion is to conduct the research with bigger population to ensure the validity and reliability of the research result. Other than that, author suggested that the data of employee performance can be changed into ordinal data or points.

\section{REFERENCES}

Ahmed, M. \& A. B. A. (2014). The Impact of Indirect Compensation on Employee performance: an Overview. Journal of Public Policy and Administration Research, 4(6), 27-30.

Becker, B. E., \& Gerhart, B. (1996). The Impact of Human Resource Management on Organizational Performance: Progress and prospects. The Academy of Management Journal, 39(4), 779-801.

Becker, B. E., \& Huselid, M. A. (1998). High Performance Work Systems and Firm Performance: A Synthesis of Research and Managerial Implications. Research in Personnel and Human Resources Management, 16, 53-101.

Bloom, M., \& Michel, J. (2002). The Relationship among Organizational Context, Pay Dispersion, and 
Managerial Turnover. The Academy of Management Journal, 45(1), 33-42.

Byars, L. L., \& Rue, L. W. (2008). Human Resource Management (9th ed.). New York: McGraw-Hill Irwin. Dessler, G. (2011). Fundamentals of human resource management. London: Pearson Hill.

Sedarmayanti. (2011). Manajemen Sumber Daya Manusia, Reformasi Birokrasi dan Manajemen Pegawai Negeri Sipil. Bandung: PT Refika Aditama. 
The Effect of Indirect Compensation on Employee Performance in Daluman Villa Kuta Bali Sri Sukmawati Wijaya, Luh Putu Kartini, I Ketut Surata, Raissa Puspita

\section{Halaman ini sengaja dikosongkan}

110 | Barista: Jurnal Kajian Bahasa dan Pariwisata, Volume 7 Nomor 2, 2020: 97-110 